\title{
Natural products active against African trypanosomes: a step towards new drugs
}

Sara Hoet, ${ }^{* a}$ Frederik Opperdoes, ${ }^{b}$ Reto Brun ${ }^{c}$ and Joëlle Quetin-Leclercq ${ }^{a}$

${ }^{a}$ Laboratoire de Pharmacognosie, Unité d'Analyse Chimique et Physico-Chimique des Médicaments, Université Catholique de Louvain, UCL 72.30-CHAM, Av. E. Mounier 72, 1200 Brussels, Belgium. E-mail: sara.hoet@cham.ucl.ac.be

${ }^{b}$ Research Unit for Tropical Diseases, Christian de Duve Institute of Cellular Pathology and

Laboratory of Biochemistry, Université Catholique de Louvain, Av. Hippocrate 74-75,

1200 Brussels, Belgium

${ }^{c}$ Medical Parasitology and Infection Biology, Parasite Chemotherapy, Swiss Tropical Institute, Socinstrasse 57, CH-4002 Basel, Switzerland

Received (in Cambridge, UK) 9th September 2003

First published as an Advance Article on the web 5th May 2004

Covering: mid-1980s up to June 2003

This review covers compounds with activity on African trypanosomes (mainly Trypanosoma brucei subsp., T. congolense and T. vivax) isolated from natural sources and is organized according to the structure of the metabolites (alkaloids, phenolic derivatives, quinones, terpenes and other metabolites). The literature from the mid-1980s up to June 2003 is reviewed and 89 references are cited.

Sara Hoet was born in Lima, Peru in 1976. She obtained her Masters in Pharmaceutical Sciences from the Universite Catholique de Louvain (Belgium) in 1999. Since 2000, she has been pursuing her PhD studies at the Université Catholique de Louvain in the laboratory of pharmacognosy headed by Prof. J. Quetin-Leclercq as a research fellow of the Belgian National Fund for Scientific Research. As part of her PhD research, she is analysing the composition of African plants which are traditionally used to treat sleeping sickness with the aim of isolating the active principles.

Fred Opperdoes (58) is full professor of biochemistry at the Catholic University of Louvain and member of the directorate of the Christian de Duve Institute of Cellular Pathology. His main interest is carbohydrate metabolism of the Trypanosomatidae as a potential target for drug development and he has published over 150 papers in this area.

Reto Brun received his PhD in Biology in 1973 from the University of Basel. From 1974 to 1976 he was a post-doctoral fellow at the University of California at Irvine in the lab of Prof. Stuart M. Krassner working on transformation processes of Leishmania. During the following 20 years he studied various aspects of African trypanosomes at the Swiss Tropical Institute (STI) in Basel and during many short stays as a visiting scientist in Africa. The development of in vitro assays for trypanosomes and other protozoan parasites offered the possibility of doing drug discovery work for tropical diseases. Today Reto Brun is head of the Parasite Chemotherapy Unit at STI and professor for biology at the University of Basel. His lab is a reference screening center for TDR/WHO Drug Discovery Research and also for the Medicines for Malaria Venture (MMV) Foundation. His research interests are drug discovery and development work for malaria and African sleeping sickness and the control of the latter disease in collaboration with African national institutions.

Joëlle Quetin-Leclercq is a pharmacist and received her PhD in pharmaceutical sciences in 1989 from the University of Liege where she mainly worked on alkaloids from Strychnos. She moved to the Université Catholique de Louvain in 1995 where she is now professor of pharmacognosy and drug analysis, director of the laboratory of pharmacognosy and head of the analytical chemistry and drug analysis unit. Her main research interests deal with plants used in African traditional medicine: analysis of their activity, isolation and structure determination of their active molecules, quantification in plants or crude extracts and quality control, in collaboration with several African partners.

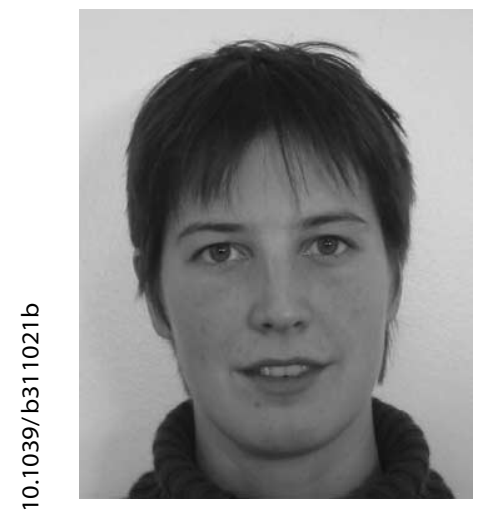

Sara Hoet

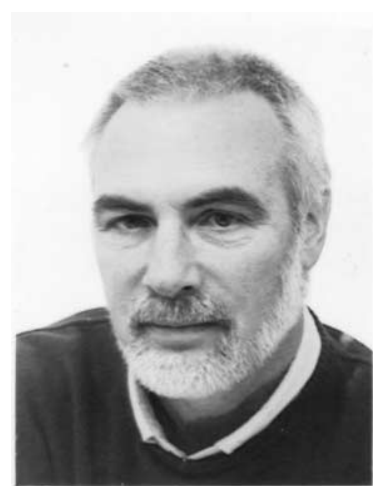

Fred Opperdoes

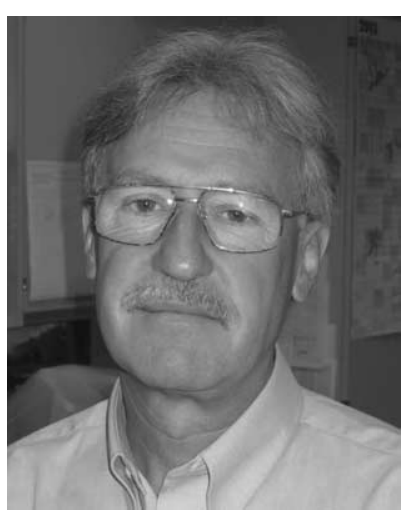

Reto Brun

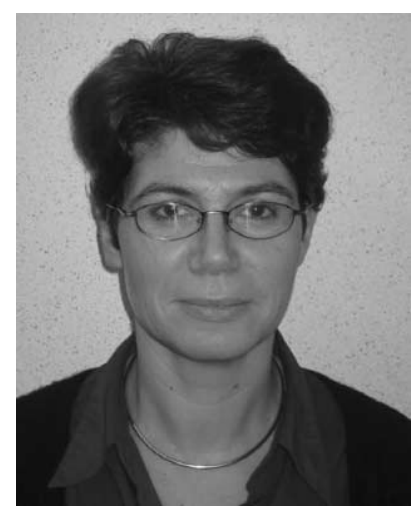

Joëlle Quetin-Leclercq 
1 Introduction

2 Natural products with antitrypanosomal activity

2.1 Alkaloids

2.2 Phenolic derivatives

2.3 Quinones

2.4 Terpenes

2.5 Other metabolites

3 Summary

4 Acknowledgments

5 References

\section{Introduction}

African trypanosomiasis is a vector-borne parasitic disease which is causing major health and economic problems in rural sub-Saharan Africa. The etiologic agents of the disease are flagellated protozoa that belong to the genus Trypanosoma: Trypanosoma brucei rhodesiense and $T$. $b$. gambiense cause human sleeping sickness and T. b. brucei (which is morphologically and biochemically indistinguishable from the two other subspecies), $T$. congolense and T. vivax cause nagana in livestock (cattle, sheep and goats). The parasites are transmitted between vertebrate hosts by the tsetse fly (Glossina spp.). ${ }^{1,2}$ Two other important livestock trypanosome species are T. evansi and T. equiperdum causing surra and dourine which are transmitted by biting flies or during coitus, respectively. ${ }^{3}$

In the 1960s, human African trypanosomiasis (HAT) was brought under control thanks to a combination of measures including treatment of patients, active case finding and vector control. However, since the 1970's, the disease has re-emerged dramatically. Sleeping sickness is again endemic in over 30 African countries threatening over 60 million people and has reached epidemic proportions in some countries, such as Angola, southern Sudan, Uganda and the Democratic Republic of Congo. Almost 45000 cases of HAT were reported in 1999 but the World Health Organization estimates that the actual number of cases is between 300000 and 500000 , since only 3-4 million people at risk of infection are under surveillance with regular examination or access to health centers. $^{4,5}$

HAT exists in two clinical forms depending on the parasite involved: a chronic form caused by $T$. $b$. gambiense affecting countries in west and central Africa and an acute form, caused by $T$. $b$. rhodesiense in east and southern Africa. Infection with either subspecies is fatal, if left untreated, in a matter of weeks (T. b. rhodesiense) or within months or years (T. b. gambiense) ${ }^{2}$ Animal infection with T. b. brucei produces, in some species, no apparent symptoms (e.g. goats, pigs and antelopes) while in others (e.g. cattle and dogs) it can be fatal. Cattle infected with $T$. congolense or $T$. vivax are chronically ill, show reduction in milk production, in weight gain and reproduction and eventually die. Nagana is thus a serious obstacle to the cattle industry in Africa. ${ }^{6 a}$

African trypanosomes undergo life cycles which alternate between a vertebrate host (blood and other body fluids, and tissues) and the tsetse fly (gut and salivary glands) (Fig. 1). ${ }^{6 b}$ To survive in these different environments, various metabolic and morphological changes are necessary which involve the mitochondrial system and the surface membrane. During a blood meal on an infected mammal, the vector ingests bloodstream trypomastigotes. The parasites multiply in the fly and go through several developmental stages (procyclics, epimastigotes and metacyclic trypanosomes) in a period of three to four weeks. When the blood-sucking fly bites another mammal, it injects metacyclic trypanosomes which transform into bloodstream trypomastigotes in the skin, and subsequently disseminate into the bloodstream via the lymphatic system. The parasites proliferate in waves, evading the host's immune system by continuously changing their antigenic coat of variant surface glycoproteins. ${ }^{2,6 b, 7}$

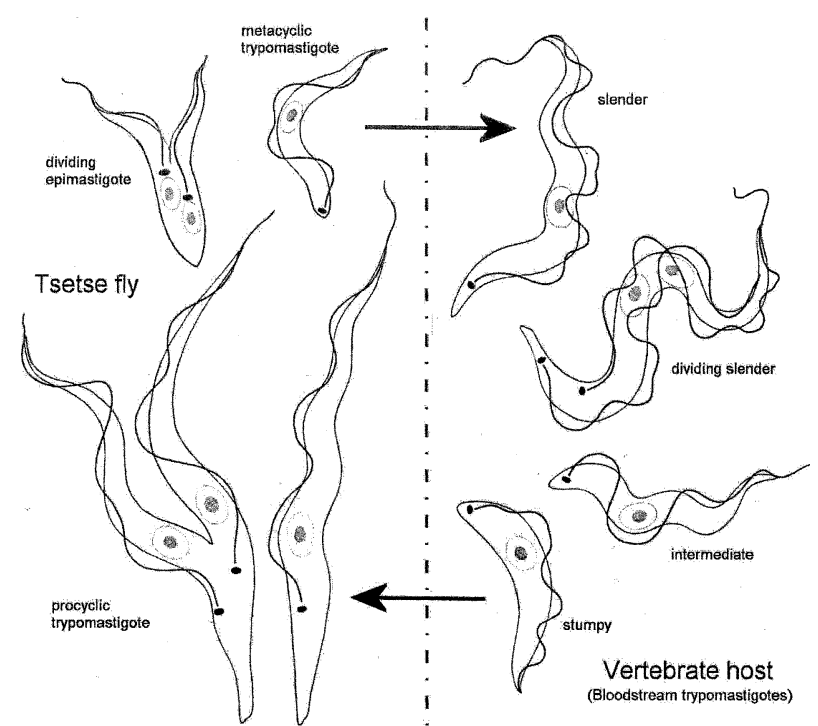

Fig. 1 The life cycle of Trypanosoma brucei subsp. (modified from K. Vickerman, 1967). ${ }^{6 b}$

This first haemolymphatic stage of the disease, which appears one to three weeks after inoculation, is characterized by non-specific symptoms such as irregular bouts of fever, headaches, joint pains and itching which are very often misinterpreted as influenza or malaria. After weeks or months depending on the parasite involved, trypanosomes cross the blood-brain barrier to invade the central nervous system resulting in a chronic meningo-encephalitis eventually leading to encephalopathy. During this second stage of HAT, characteristic symptoms appear: headaches, neurological symptoms, personality and behavior alterations, poor coordination, changes in the sleep cycle (giving the disease its name) and body wasting, leading eventually to a terminal somnolent state and finally to death if left untreated. An early diagnosis as well as early treatment are thus important for a better management of the second stage of the disease. ${ }^{2,7}$

Current chemotherapeutic options are very limited and far from ideal. There are only four approved drugs for HAT, three of which were developed more than half a century ago: suramin, pentamidine, melarsoprol and eflornithine (Fig. 2). Other molecules such as homidium, isometamidium, and diminazene aceturate are used in animal infections. Only melarsoprol and eflornithine, which are able to cross the blood-brain barrier, can be used for the second stage, with eflornithine only effective in T. b. gambiense infection. The mechanisms of action of these molecules remain poorly understood except for eflornithine, which inhibits the polyamine biosynthesis pathway. All these drugs have to be administered by injection over a long period of time thus requiring medical facilities and specialized staff which often do not exist in rural areas. Adverse effects are severe, sometimes life-threatening. There are also increasing reports of treatment failures, especially with melarsoprol. The availability of these drugs has not always been guaranteed as drug companies periodically abandon production because of lack of profitability. Therefore, there is an urgent need for new molecules against sleeping sickness which are safe, effective, cheap and easy-to-administer and for new leads with novel mechanisms of action. ${ }^{8-11}$

Nature with its numerous plants, microorganisms and marine organisms is a potential source of such new drugs since it contains a countless quantity of molecules with a great variety of structures and pharmacological activities. ${ }^{12}$ Throughout the ages, mineral, plant and animal products have been the main sources of medicines for man. It is estimated that two thirds of the world population still rely on traditional medical remedies, mainly plants, because of limited availability or affordability of pharmaceutical medicines. ${ }^{13}$ Several well established human 
<smiles>CCNc1cccc(C(=O)Nc2cc(C(=O)Nc3ccc(S(=O)(=O)O)c4cc([O-])cc([As](=O)O)c34)ccc2C)c1</smiles>

Suramin<smiles>N=C(N)c1ccc(OCCCCCOc2ccc(C(=N)N)cc2)cc1</smiles><smiles>Nc1nc(N)nc(Nc2ccc([As]3SCC(CO)S3)cc2)n1</smiles>

Melarsoprol<smiles>NCCCC(N)(C(=O)O)C(F)F</smiles>

Eflornithine

Pentamidine

AT.

antiprotozoal drugs have their origins in nature, such as quinine, an alkaloid from Cinchona sp. (Rubiaceae) and artemisinin, a sesquiterpene lactone from Artemisia annua (Asteraceae) used to treat malaria, or emetine, an alkaloid from Cephaelis ipecacuanha (Rubiaceae) used to treat amoebiasis. Additionally, these antiprotozoal plant-derived compounds have been used as leads to develop other semi-synthetic or synthetic drugs with better efficacy, safety or pharmacokinetic profiles. ${ }^{13}$

The diversity of natural products with antiprotozoal activities has been illustrated in several reviews which cover molecules that are mainly active on the etiological agents of malaria, leishmaniasis or Chagas' disease. ${ }^{14-19}$ This review includes the natural products that are active on the trypanosomes responsible for sleeping sickness and nagana.

Publications reporting the activity of plant extracts on African trypanosomes are not abundant compared to other protozoal diseases such as malaria. There are even less publications on this subject with regard to isolated natural products. The majority of these compounds have been tested for their in vitro activity on bloodstream trypomastigotes of African trypanosomes. Additionally, the in vitro cytotoxicity for mammalian cells of several of these natural metabolites was at the same time assessed allowing the determination of the selectivity of their in vitro antitrypanosomal effect, which is expressed by the selectivity index $\left(\mathrm{SI}=\right.$ ratio of the $\mathrm{IC}_{50}$ value obtained for mammalian cells divided by the $\mathrm{IC}_{50}$ on trypanosomes). Even if this in vitro selectivity index does not allow extrapolation to the in vivo situation, this parameter is valuable for selecting compounds with a selective activity against trypanosomes that are worth investigating, for example in animal models. ${ }^{20}$ Only a few natural compounds have been evaluated for in vivo activity in animals and none have been assessed clinically.

In this review, the compounds are grouped according to their structures in 5 categories: alkaloids, phenolic derivatives, quinones, terpenes and other metabolites. Some of the in vitro antitrypanosomal or cytotoxic activities reported in the literature were transformed into molar concentrations $(\mu \mathrm{M})$ to allow a better comparison independent of their molecular weight. Nevertheless comparison remains complex due to the different assay procedures used in the various laboratories. These differences are evident when comparing the values obtained for the reference drugs.

\section{Natural products with antitrypanosomal activity}

\subsection{Alkaloids}

Several alkaloids have been tested on trypanosomes in vitro. In a study of 34 different alkaloids, those with a piperidine, pyridine, tropane, quinolizidine, indole, or purine skeleton were found, in general, to be inactive on T. b. brucei and T. congolense bloodstream forms and non cytotoxic for the human myeloid cell line HL-60. ${ }^{21}$ However, a number of isoquinoline and quinoline alkaloids exhibited $\mathrm{IC}_{50}$ values below $10 \mu \mathrm{M}$. T. congolense was always less susceptible to these compounds than T. b. brucei. The quinoline alkaloids from Cinchona bark (Rubiaceae) (quinidine 1, cinchonine 2, quinine 3, cinchonidine 4) had significant trypanocidal activity with $\mathrm{IC}_{50}$ values of $0.8,1.2,4.9,7.1 \mu \mathrm{M}$, respectively, on $T$. b. brucei. For $\mathbf{1}$ and $\mathbf{2}$, the selectivity indices were greater than 200, indicating the potential of these alkaloids for further drug development. Emetine 5, an isoquinoline alkaloid from Cephaelis ipecacuanha (Rubiaceae) which has been used in the treatment of amoebiasis, was very trypanocidal $\left(\mathrm{IC}_{50}=0.039 \mu \mathrm{M}\right.$ and $0.43 \mu \mathrm{M}$ for $T$. b. brucei and T. congolense) but without any selectivity. Berberine 6 and sanguinarine 7, two quaternary benzylisoquinoline alkaloids found in a number of plant families, and berbamine 8, a bisbenzylisoquinoline (BBIQ), were trypanocidal with little or no selectivity $\left(\mathrm{IC}_{50}=0.5,1.9,2.6 \mu \mathrm{M}\right.$ on $T$. b. brucei respectively with $\mathrm{SI}=51,0.7,7)$. DNA intercalation in combination with the inhibition of protein synthesis could be responsible for the observed trypanocidal and cytotoxic effects of these different alkaloids. ${ }^{21}$

Out of the 12 BBIQ alkaloids tested by Camacho et al. on T. b. brucei bloodstream trypomastigotes, eight had an $\mathrm{IC}_{50}$ between 1 and $2 \mu \mathrm{M}$, but none were as active as pentamidine. ${ }^{22}$

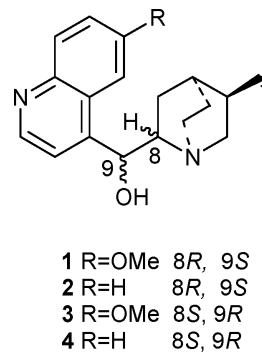


<smiles>CC[C@H]1CN2CCc3cc(OC)c(OC)cc3[C@H]2C[C@H]1C[C@H]1NCCc2cc(OC)c(OC)cc21</smiles>

5<smiles>COc1ccc2cc3[n+](cc2c1OC)CCc1cc2c(cc1-3)OCO2</smiles><smiles>C[n+]1cc2c3c(ccc2c2ccc4cc5c(cc4c21)OCO5)OCO3</smiles>

7
Thalisopidine 9 displayed the strongest trypanocidal activity $\left(\mathrm{IC}_{50}=1.1 \mu \mathrm{M}\right)$. Berbamine 8 was active on $T$. b. brucei in the same concentration range as reported in the previous study. Phaeanthine 10, isolated from the leaves of Triclisia patens (Menispermaceae) was active on $T$. b. brucei in vitro $\left(\mathrm{IC}_{50}=\right.$ $1.7 \mu \mathrm{M}$ ) but in another study it was shown to be inactive in mice infected with the same parasite. ${ }^{22,23}$ No clear structure-activity relationship could be extracted from this study of several BBIQ alkaloids.
Naphthylisoquinoline (NIQ) alkaloids are axially chiral natural biaryls isolated from African plants belonging to the small Ancistrocladaceae and Dioncophyllaceae families which have already shown promising antiprotozoal properties, in particular antiplasmodial activity. Among the monomeric NIQ alkaloids tested up to now, dioncophyllines A 11, B 12 and E 13 were the most active with $\mathrm{IC}_{50}$ values of $2-3 \mu \mathrm{M}$ on $T$. b. brucei or T. b. rhodesiense bloodstream forms. ${ }^{24,25}$ Ancistroealaines A 14 and B 15, isolated from the stem bark of Ancistrocladus ealaensis (Ancistrocladaceae) display a lower activity on T. b. rhodesiense ( $\mathrm{IC}_{50}$ of 8 and $5 \mu \mathrm{M}$ respectively) but exhibited cytotoxic effects on mammalian L6 cells (rat skeletal myoblasts) at much higher concentrations $\left(\mathrm{IC}_{50}>215 \mu \mathrm{M}\right.$ for $\mathbf{1 4}$ and $=220$ $\mu \mathrm{M}$ for 15$){ }^{26}$ Dioncopeltine A 16 , with its additional alcohol function on the methyl group of the naphthalene ring, has a distinctly lower activity on $T$. $b$. brucei bloodstream trypomastigotes $\left(\mathrm{IC}_{50}=22 \mu \mathrm{M}\right)$ and habropetaline A 17 , isolated from the root of Triphyophyllum peltatum (Dioncophyllaceae) was inactive. ${ }^{24,27}$ The dimeric NIQ, ancistrogriffithine A 18, obtained from the twigs of Ancistrocladus griffithii (Ancistrocladaceae), had trypanocidal activity $\left(\mathrm{IC}_{50}=1.2 \mu \mathrm{M}\right.$ on $T$. b. rhodesiense) but unfortunately showed some cytotoxicity $\left(\mathrm{IC}_{50}=7.4 \mu \mathrm{M}\right.$ on L6 cells). ${ }^{28}$ The anti-HIV dimeric NIQ, michellamine B 19, was, on the contrary, devoid of any antitrypanosomal activity. ${ }^{24}$ Bringmann et al. also tested compounds corresponding to the two bicyclic parts of NIQ alkaloids, as well as molecules related to the central biaryl core to try to elucidate the structural prerequisites for good antitrypano-

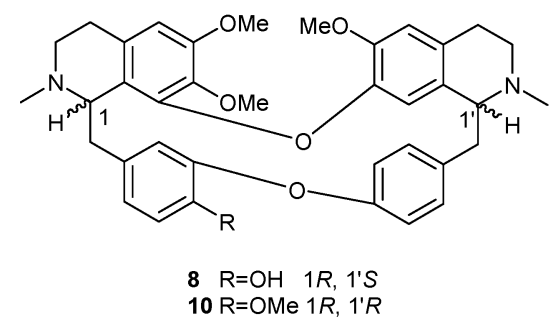

$10 \mathrm{R}=\mathrm{OMe} 1 R, 1^{\prime} R$<smiles>[R]c1cc(OC)c2c([R])cccc2c1-c1ccc2c(c1O)[C@@H](C)N[C@H](C)C2</smiles>

$11 \mathrm{R}^{1}=\mathrm{Me}, \mathrm{R}^{2}=\mathrm{OMe}$ $16 \mathrm{R}^{1}=\mathrm{CH}_{2} \mathrm{OH}, \mathrm{R}^{2}=\mathrm{OH}$ $17 \mathrm{R}^{1}=\mathrm{CH}_{2} \mathrm{OH}, \mathrm{R}^{2}=\mathrm{OMe}$<smiles>[R][R]([R]([Y19])=[R]([R])[R])c1cc([R])cc2cc([R1])c(-c3ccc4c(c3O)[C@@H](C)N[C@H](C)C4)c(O)c12</smiles>

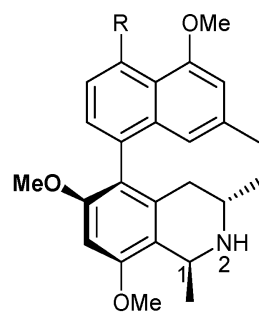

$14 \mathrm{R}=\mathrm{OMe} 1,2$ dehydro $15 \mathrm{R}=\mathrm{OH}$

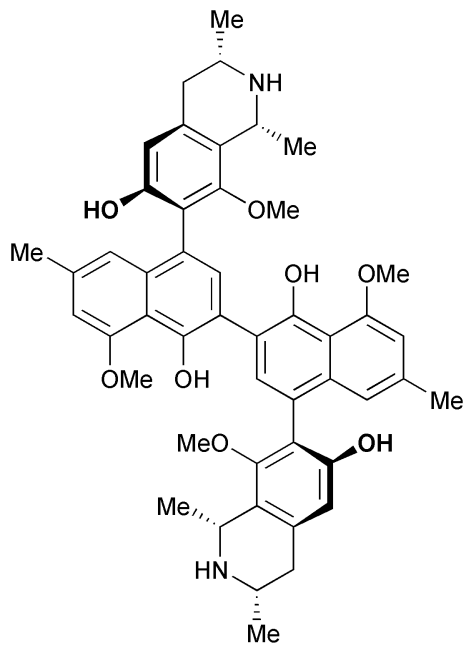

18

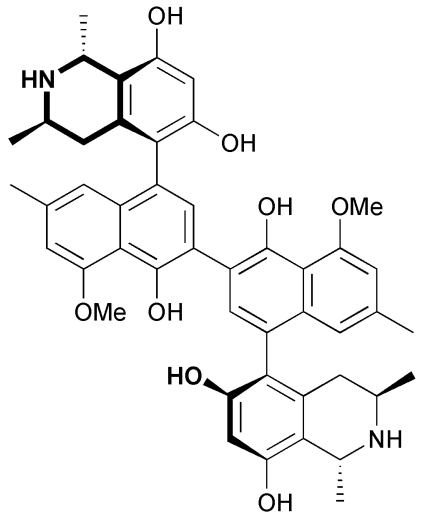


somal activity. Among all compounds tested, the natural, genuine alkaloids themselves, showed the highest activities. ${ }^{24}$ NIQ alkaloids could thus constitute an interesting class of antitrypanosomal compounds worth further optimization. ${ }^{24-30}$

Out of the three oxoaporphines $(O$-methylmoschatoline $\mathbf{2 0}$, lysicamine 21, liriodenine 22) isolated by activity-directed fractionation from the stem bark of Unonopsis buchtienii (Annonaceae), only 20 showed some activity on the mammalian stage of T. b. brucei $\left(\mathrm{IC}_{100}=20 \mu \mathrm{M}\right)$ but without selectivity. ${ }^{31}$ In a study which compared the in vitro antitrypanosomal activity of seven aporphines, only the three alkaloids isolated from Cassytha filiformis (Lauraceae) were active on T. b. brucei bloodstream trypomastigotes: actinodaphnine 23, cassythine $\mathbf{2 4}$ and dicentrine $\mathbf{2 5}$ had $\mathrm{IC}_{50} \mathrm{~s}$ of $3.2,6.0$, and $14.6 \mu \mathrm{M}$, respectively but were also toxic to HeLa cells $(\mathrm{SI}<5)$. The antitrypanosomal activity of these aporphines, which intercalate into DNA, seemed to be related to their ability to stabilize the DNA helix against heat denaturation and to inhibit the catalytic activity of topoisomerase $\mathrm{I}^{32}$ Bulbocapnine $\mathbf{2 6}$ was inactive in vitro and in vivo on $T$. b. brucei, providing some structure-activity relationships. ${ }^{23,32}$<smiles></smiles>

$20 \mathrm{R}^{1}, \mathrm{R}^{2}, \mathrm{R}^{3}=\mathrm{OMe}$ $21 \mathrm{R}^{1}, \mathrm{R}^{2}=\mathrm{OMe}, \mathrm{R}^{3}=\mathrm{H}$ $22 \mathrm{R}^{1}-\mathrm{R}^{2}=-\mathrm{O}-\mathrm{CH}_{2}-\mathrm{O}-, \mathrm{R}^{3}=\mathrm{H}$

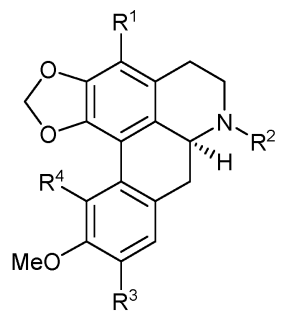

$23 \mathrm{R}^{1}, \mathrm{R}^{2}, \mathrm{R}^{4}=\mathrm{H}, \mathrm{R}^{3}=\mathrm{OH}$ $25 \mathrm{R}^{1}, \mathrm{R}^{4}=\mathrm{H}, \mathrm{R}^{2}=\mathrm{Me}, \mathrm{R}^{3}=\mathrm{OMe}$ $26 \mathrm{R}^{1}, \mathrm{R}^{3}=\mathrm{H}, \mathrm{R}^{2}=\mathrm{Me}, \mathrm{R}^{4}=\mathrm{OH}$ $24 \mathrm{R}^{1}=\mathrm{OMe}, \mathrm{R}^{2}, \mathrm{R}^{4}=\mathrm{H}, \mathrm{R}^{3}=\mathrm{OH}$

The plants of the Amaryllidaceae family are often toxic and contain a special class of isoquinoline alkaloids, especially in the bulbs. ${ }^{33-36}$ Pancracine 27, an alkaloid, with a 5,11-methanomorphanthridine ring, obtained from the fresh bulb of Narcissus angustifolius subsp. transcarpathicus was active on the mammalian stage of $T$. $b$. rhodesiense with an $\mathrm{IC}_{50}$ of $2.4 \mu \mathrm{M}$ and was not cytotoxic for L6 cells at concentrations up to $300 \mu \mathrm{M} .{ }^{36}$ Nangustine 28, a regioisomer of pancracine, was also devoid of cytotoxicity but was almost 14 times less active $\left(\mathrm{IC}_{50}=33.4 \mu \mathrm{M}\right)$ on the trypanosomes. ${ }^{36}$ The antitrypanosomal activity of some Amaryllidaceae alkaloids of the crinane type were evaluated on $T$. $b$. rhodesiense bloodstream forms: haemanthidine 29 was active with an $\mathrm{IC}_{50}$ of $3.5 \mu \mathrm{M}$, oxomaritidine 30 was weakly active $\left(\mathrm{IC}_{50}=9.8 \mu \mathrm{M}\right)$, and maritidine 31 was inactive. ${ }^{34,35}$ Galanthine 32, an alkaloid of the lycorane type had the same activity on trypanosomes as $\mathbf{3 0} .^{35}$

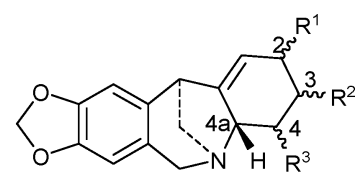

$27 \mathrm{R}^{1}, \mathrm{R}^{2}=\mathrm{OH}, \mathrm{R}^{3}=\mathrm{H} 2 \mathrm{~S}, 3 \mathrm{~S}, 4 \mathrm{aS}$ $28 \mathrm{R}^{1}=\mathrm{H}, \mathrm{R}^{2}, \mathrm{R}^{3}=\mathrm{OH} 3 S, 4 S, 4 a R$

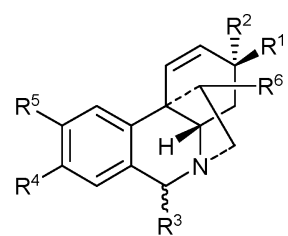

$29 \mathrm{R}^{1}=\mathrm{OMe}, \mathrm{R}^{2}=\mathrm{H}, \mathrm{R}^{3}, \mathrm{R}^{6}=\mathrm{OH}, \mathrm{R}^{4}-\mathrm{R}^{5}=\mathrm{O}-\mathrm{CH} 2-\mathrm{O}$ $30 R^{1}-R^{2}=O, R^{3}, R^{6}=H, R^{4}, R^{5}=O M e$ $31 \mathrm{R}^{1}=\mathrm{OH}, \mathrm{R}^{2}, \mathrm{R}^{3}, \mathrm{R}^{6}=\mathrm{H}, \mathrm{R}^{4}, \mathrm{R}^{5}=\mathrm{OMe}$<smiles>COc1cc2c(cc1OC)[C@H]1[C@H](O)[C@H](OC)C=C3CCN(C2)[C@H]31</smiles>

32

Several alkaloids isolated from marine organisms such as sponges, ascidians and tunicates have been evaluated for their antitrypanosomal activity. ${ }^{37-39}$ Lepadins D 33, E 34 and F 35 isolated from a tunicate species from the genus Didemnum, possess an unusual decahydroquinoline skeleton and show significant and selective antitrypanosomal activity in vitro. Compounds 35 and $\mathbf{3 4}$, two diastereoisomers, displayed an $\mathrm{IC}_{50}$ on T. b. rhodesiense bloodstream trypomastigotes inferior to $1 \mu \mathrm{M}$ and were respectively 80 to 43 times less toxic on L6 mammalian cells. Compound 33 was weakly active with an $\mathrm{IC}_{50}$ on trypanosomes of $19 \mu \mathrm{M}$. The presence of the $2-E$-octenoic acid ester function at $\mathrm{C}_{3}$ in $\mathbf{3 4}$ and $\mathbf{3 5}$ in place of the secondary hydroxyl function increased the antitrypanosomal activity significantly. ${ }^{37}$ Fascaplysin 36, a quaternary indole alkaloid isolated from the sponge Hyrtios erecta, was also active on the mammalian stage of $T$. $b$. rhodesiense $\left(\mathrm{IC}_{50}=0.6 \mu \mathrm{M}\right)$ but was cytotoxic to L6 cells. ${ }^{38}$ Two pyridoacridone alkaloids, ascididemin 37 and 2-bromoascididemin 38 are other marine metabolites. Compound 37 is a pentacyclic DNA intercalating agent with marked cytotoxic activities. The two compounds were more cytotoxic to macrophages $\left(\mathrm{IC}_{50}=6\right.$ and $0.7 \mu \mathrm{M}$ for 37 and 38 respectively) than to $T$. $b$. rhodesiense bloodstream forms $\left(\mathrm{IC}_{50}=14\right.$ and $5 \mu \mathrm{M}$, respectively). ${ }^{39}$ Several related synthetic derivatives were also tested for their antitrypanosomal activities. The two most active compounds $\mathbf{3 9}$ and $\mathbf{4 0}$ were respectively 2000 and 770 times more trypanocidal than the parent compound $37\left(\mathrm{IC}_{50}=0.007\right.$ and $0.018 \mu \mathrm{M}$, respectively, while $\mathrm{IC}_{50}$ for melarsoprol, the reference drug, $=0.003 \mu \mathrm{M}$ ) but the cytotoxicity did not vary $\left(\mathrm{IC}_{50}=6-7 \mu \mathrm{M}\right)$. The authors speculate that the mechanisms of action of these derivatives involve DNA intercalation and DNA oxidative damage. ${ }^{39}$

The indoloquinoline alkaloids, cryptolepine $\mathbf{4 1}$ and neocryptolepine 42, isolated from Cryptolepis sanguinolenta (Periplocaceae) were shown to be potent antiplasmodial compounds. When tested on $T$. $b$. brucei bloodstream forms, their $\mathrm{IC}_{50} \mathrm{~s}$ were 3 and $4 \mu \mathrm{M}$, respectively. However these compounds, especially $\mathbf{4 1}$, are cytotoxic, due to DNA interaction and inhibition of topoisomerase $\mathrm{II}\left(\mathrm{IC}_{50}\right.$ on a human embryonic lung cell line MRC-5 = 1.5 and $11 \mu \mathrm{M}$ for $\mathbf{4 1}$ and $\mathbf{4 2}$, respectively). The synthesis of neocryptolepine derivatives such as 2-nitroneocryptolepine $\mathbf{4 3}$ has led to compounds with an $\mathrm{IC}_{50}$ on T. b. brucei of $0.7 \mu \mathrm{M}$ whereas the $\mathrm{IC}_{50}$ on MRC-5 cells was greater than $32 \mu \mathrm{M}$ constituting a new lead structure with antitrypanosomal potential. ${ }^{40}$

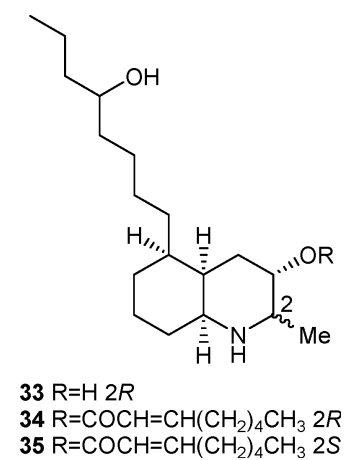

Tryptanthrin 44 (indolo[2,1-b]quinazoline-6,12-dione) is unusual in that its synthesis was described 50 years before it was discovered in a number of plant species. Scovill et al. 


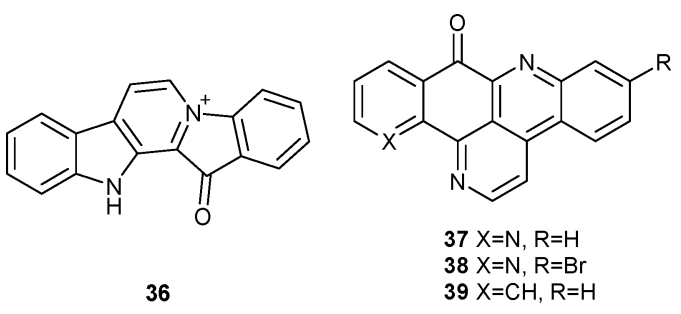<smiles>Cc1c2c(nc3ccccc13)C(=O)c1cccnc1C2=O</smiles>

40

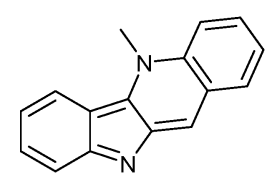

41

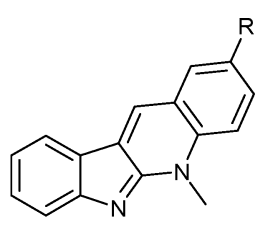
$42 \mathrm{R}=\mathrm{H}$
$43 \mathrm{R}=\mathrm{NO}_{2}$ studied the in vitro activities of $\mathbf{4 4 , 4 - a z a t r y p t a n t h r i n ~} \mathbf{4 5}$, and a series of substituted derivatives against bloodstream forms of T. b. brucei.$^{41}$ The unsubstituted compounds were weakly active $\left(\mathrm{IC}_{50}=23\right.$ and $40 \mu \mathrm{M}$ for $\mathbf{4 4}$ and $\mathbf{4 5}$ respectively). The antitrypanosomal activity was markedly improved by the presence of an electron-withdrawing group (halogen or nitro) at position 8 of the (aza)tryptanthrin ring system: the most active analog of the series, 4-aza-8-bromotryptanthrin $\mathbf{4 6}$, was up to 100 times more active than the unsubstituted parent compound $45\left(\mathrm{IC}_{50}=0.4 \mu \mathrm{M}\right){ }^{41}$

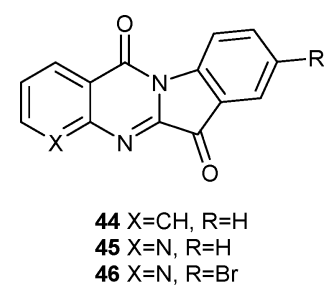

Camptothecin 47, a pentacyclic alkaloid from Camptotheca acuminata (Nyssaceae), is a well known antitumor agent and a specific inhibitor of human DNA topoisomerase I. Bodley et al. have shown that $\mathbf{4 7}$ also inhibits the nuclear and mitochondrial topoisomerase I of $T$. $b$. brucei thus blocking DNA replication and inducing the death of bloodstream trypomastigotes $\left(\mathrm{IC}_{50}=\right.$ $1.6 \mu \mathrm{M}){ }^{42}$ In a study of a series of camptothecin analogs, the 9-substituted-10,11-methylenedioxy derivatives were significantly more active on $T$. $b$. brucei bloodstream trypomastigotes than the parent compound and retained as intracellular target the parasites' topoisomerase I. For example, 9-chloro-10,11methylenedioxycamptothecin $\mathbf{4 8}$ was 40 times more trypanocidal than $47\left(\mathrm{IC}_{50}=0.041 \mu \mathrm{M}\right)$. Additionally, these structural changes cause a disproportionate increase in antitrypanosomal activity compared with toxicity on mouse L1210 leukemia cells ( $\mathrm{SI}=0.3$ and 0.075 for $\mathbf{4 8}$ and $\mathbf{4 7}$, respectively). Although these camptothecin derivatives remained more toxic for mammalian cells than for trypanosomes, these findings suggest the 9-substituted-10,11-methylenedioxy structural motif as a starting point for attaining selective toxicity. ${ }^{42,43}$

\subsection{Phenolic derivatives}

Ascofuranone 49, a prenylated phenol antibiotic isolated from a phytopathogenic fungus, Ascochyta visiae, is a potent and specific inhibitor of the glycerol-3-phosphate-dependent

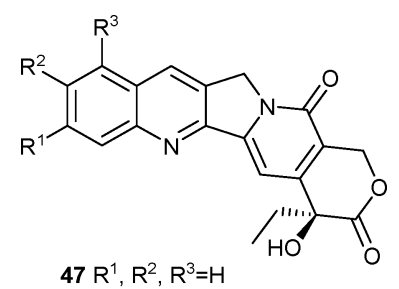

$48 \mathrm{R}^{1}-\mathrm{R}^{2}=-\mathrm{O}-\mathrm{CH}_{2}-\mathrm{O}-, \mathrm{R}^{3}=\mathrm{Cl}$

mitochondrial oxygen consumption of $T$. b. brucei bloodstream forms. The specificity is due to the presence of a unique mitochondrial electron transport system in trypanosome bloodstream forms. It is composed of two enzymes, a glycerol3-phosphate dehydrogenase and the trypanosome alternative oxidase (TAO), a ubiquinol:oxygen oxidoreductase. The two enzymes interact via ubiquinone, also known as coenzyme Q. The mechanism of action of $\mathbf{4 9}$, which has a structure analogous to that of coenzyme Q, is attributed to its binding at the coenzyme $\mathrm{Q}$ site of the ubiquinol oxidase, thus blocking the TAO. It has been demonstrated that in combination with glycerol, which suppresses a glycerol-producing anaerobic pathway by mass action, inhibitors of the TAO become trypanocidal due to a total block of the energy production of bloodstream forms. ${ }^{44}$ Compound $\mathbf{4 9}$ was potently trypanocidal in vitro for $T$. b. brucei bloodstream forms only when combined with glycerol $4 \mathrm{mM}\left(\mathrm{IC}_{100}\right.$ without glycerol $=250 \mu \mathrm{M}, \mathrm{IC}_{100}$ with glycerol $=0.03 \mu \mathrm{M}) .{ }^{45}$ First in vivo studies have shown that 49 at $100 \mathrm{mg} \mathrm{kg}^{-1}$ combined with glycerol $3 \mathrm{~g} \mathrm{~kg}^{-1}$ given orally or at $25 \mathrm{mg} \mathrm{kg}^{-1}$ combined with glycerol $3 \mathrm{~g} \mathrm{~kg}^{-1}$ given intraperitoneally gave $100 \%$ cure of mice infected with $T$. b. brucei. In each experiment, 49 was given at a single dose and glycerol was given at $1 \mathrm{~g} \mathrm{~kg}^{-1}$ at 30 minute intervals. Living trypanosomes disappeared from the blood within 30 and 180 minutes after final intraperitoneal and oral treatments, respectively. Compound 49 was also shown to be highly non-toxic in vivo and able to cross the blood-brain barrier. ${ }^{46}$ A recent study by the same researchers has shown that treatment with $\mathbf{4 9}$ alone could also have therapeutic efficacy in mice if higher doses and a longer treatment were applied. $100 \mathrm{mg} \mathrm{kg} \mathrm{kg}^{-1}$ of $\mathbf{4 9}$ given intraperitoneally for four consecutive days or $400 \mathrm{mg} \mathrm{kg}^{-1}$ given orally for eight consecutive days were necessary to cure mice. ${ }^{47}$<smiles>C/C(=C\Cc1c(O)c(C)c(C=O)c(C)c1Cl)CC/C=C(\C)C1CC(=O)C(C)(C)O1</smiles>

Other simple phenolic compounds which are widely distributed in plants have been tested for their antitrypanosomal activity as well. Gallic acid 50, a well-known component of hydrolysable tannins, is equally active on the bloodstream and procyclic forms of T. b. brucei $\left(\mathrm{IC}_{50}=15.6\right.$ and $14.4 \mu \mathrm{M}$ respectively). Gallic acid esters such as ethyl gallate $\mathbf{5 1}$ and $n$-propyl gallate 52, were more toxic to bloodstream forms than $\mathbf{5 0}\left(\mathrm{IC}_{\mathbf{5 0}}\right.$ $=2.3$ and $1.5 \mu \mathrm{M}$, respectively) but their activity on procyclic forms was weaker (32 and $29 \mu \mathrm{M}$, respectively). Syringic acid $\mathbf{5 3}$ and protocatechuic acid $\mathbf{5 4}$, which lack the pyrogallol moiety, were not toxic for bloodstream and procyclic forms $\left(\mathrm{IC}_{50}>\right.$ $100 \mu \mathrm{M}){ }^{48}$ The same researchers suggested that the formation of reactive oxygen species (such as the superoxide anion) might be involved in the gallic acid-induced trypanocidal activity, in other words, it would act as a pro-oxidant. ${ }^{49}$

Bio-guided fractionation of a stem bark extract of Combretum molle (Combretaceae) led to the isolation of two classes of compounds: two inactive saponins and two hydrolysable tannins, punicalagin $\mathbf{5 5}$ and a structurally similar compound for which the full structure has not yet been elucidated (CM-A). Those two compounds exhibited activity on the mammalian 
stage of $T . b$. rhodesiense $\left(\mathrm{IC}_{50}=1.75\right.$ and $1.5 \mu \mathrm{M}$ for $\mathbf{5 5}$ and CM-A) and were relatively less toxic to human epidermoid carcinoma KB cells ( $\mathrm{SI}=70$ and 48, respectively, for $\mathbf{5 5}$ and CM-A). These two tannins showed a relative selectivity against trypanosomes, a result which contradicts the general belief that tannins are non-selective enzyme inhibitors due to their substantial number of phenolic groups. ${ }^{50}$<smiles>[R16]OC(=O)c1cc([R])c(O)c([R])c1</smiles>

$50 \mathrm{R}_{1}=\mathrm{H}, \mathrm{R}^{2}, \mathrm{R}^{3}=\mathrm{OH}$

$51 R_{1}=$ ethyl, $R^{2}, R^{3}=\mathrm{OH}$

$52 R_{1}=n$-propyl, $R^{2}, R^{3}=\mathrm{OH}$

$53 \mathrm{R}_{1}=\mathrm{H}, \mathrm{R}^{2}, \mathrm{R}^{3}=\mathrm{OMe}$

$54 \mathrm{R}_{1}, \mathrm{R}^{2}=\mathrm{H}, \mathrm{R}^{3}=\mathrm{OH}$

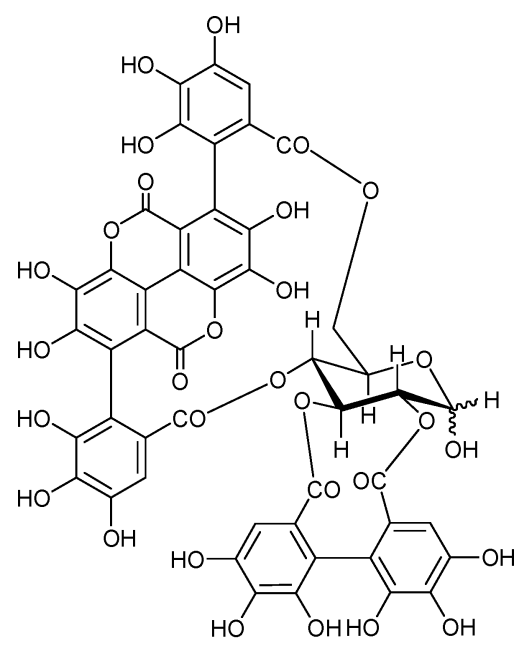

55

B. Räz evaluated the in vitro antitrypanosomal activity of 132 flavonoids from the flavone, flavonol, flavanone, isoflavone and chalcone subclasses. ${ }^{51}$ Selectivity of the effect was determined by comparing the $\mathrm{IC}_{50}$ values of flavonoids against the parasite and adenocarcinoma cells (HT-29). 48 out of the 132 flavonoids displayed an $\mathrm{IC}_{50}$ value below $10 \mu \mathrm{M}$ against $T$. $b$. rhodesiense bloodstream forms. Two compounds, 7,8-dihydroxyflavone $\mathbf{5 6}$ and quercetagetin 57, a flavonol, were selectively trypanocidal in the submicromolar range $\left(\mathrm{IC}_{50}=0.16\right.$ and $0.8 \mu \mathrm{M}, \mathrm{SI}=1019$ and 571, respectively). Most of the compounds analyzed showed a selective trypanocidal activity with selectivity indices often greater than 100 when compared to the mammalian cell toxicity. In general, flavanones, which lack a double bond between $\mathrm{C}_{2}$ and $\mathrm{C}_{3}$, were less active than their flavone counterpart. Similarly, flavonols were more trypanocidal than their flavone counterpart, which lacks the hydroxyl substituent on $\mathrm{C}_{3}$. No clear structure-activity relationships could be drawn as a wider variety of substituents would need to be introduced more systematically. ${ }^{51}$ Camacho et al. confirmed the weak antitrypanosomal activity of quercetin $58\left(\mathrm{IC}_{50}=13.2 \mu \mathrm{M}\right.$ on T. b. brucei bloodstream forms), a flavonol which only differs from quercetagetin 57 by the absence of an hydroxyl on $\mathrm{C}_{6 .}{ }^{51,52}$ Compound $\mathbf{5 8}$ has been shown to be able to inhibit the $\mathrm{F}_{1}$-ATPase of Trypanosoma cruzi, responsible for Chagas' disease. ${ }^{53}$

Four methoxylated flavones were isolated by bio-guided fractionation from the leaves of Ehretia amoena (Boraginaceae), a plant traditionally used in Uganda to treat sleeping sickness: chrysosplenetin 59, chrysosplenol D 60, retusin 61 and artemetin $\mathbf{6 2} .{ }^{51}$ Compounds $\mathbf{5 9}$ and $\mathbf{6 0}$ were the most potent on<smiles>[R]c1ccc(-c2oc3c([R])c([R])c([R])c([R])c3c(=O)c2[R])cc1[R]</smiles>

$56 R^{1}, R^{2}, R^{3}, R^{6}, R^{7}=H, R^{4}, R^{5}=\mathrm{OH}$ $57 R^{1}, R^{2}, R^{3}, R^{4}, R^{6}, R^{7}=O H, R^{5}=H$ $58 \mathrm{R}^{1}, \mathrm{R}^{2}, \mathrm{R}^{4}, \mathrm{R}^{6}, \mathrm{R}^{7}=\mathrm{OH}, \mathrm{R}^{3}, \mathrm{R}^{5}=\mathrm{H}$

T. b. rhodesiense bloodstream trypomastigotes $\left(\mathrm{IC}_{50}=2.9\right.$ and $4.7 \mu \mathrm{M}$, respectively) while 61 was less active $\left(\mathrm{IC}_{50}=14.2 \mu \mathrm{M}\right)$. Although 62 was inactive $\left(\mathrm{IC}_{50}=189 \mu \mathrm{M}\right)$, the author showed that it increases synergistically in vitro the trypanocidal activity of the three other flavones. This synergy was already reported for $\mathbf{6 2}$ which enhanced the antiplasmodial activity of artemisinin in Artemisia annua (Asteraceae). ${ }^{54}$ On the other hand, an antagonistic effect was shown when $\mathbf{5 9}$ and $\mathbf{6 1}$ were combined, which clearly illustrates the complexity of crude extract activities. ${ }^{51}$<smiles>[R]c1ccc(-c2oc3cc(OC)c([R])c(O)c3c(=O)c2OC)cc1[R]</smiles>

$$
\begin{aligned}
& 59 R^{1}, R^{2}=O M e, R^{3}=O H \\
& 60 R^{1}=O M e, R^{2}, R^{3}=O H \\
& 61 R^{1}=H, R^{2}, R^{3}=O M e \\
& 62 R^{1}, R^{2}, R^{3}=O M e
\end{aligned}
$$

From the roots of Tephrosia aequilata (Papilionaceae), four $\beta$-oxygenated chalcones were isolated. Demethylpraecansone B 63 and praecansone B 64 showed a low activity on the mammalian stage of $T$. $b$. rhodesiense $\left(\mathrm{IC}_{50}=15-16 \mu \mathrm{M}\right)$ and no cytotoxicity towards L6 cells, while praecansone A $\mathbf{6 5}$ and its $Z$-isomer 66 were inactive. ${ }^{55}$<smiles>[X]Oc1cc2c(c(O[R])c1C(=O)/C=C(\O)c1ccccc1)C=CC(C)(C)O2</smiles>

$63 \mathrm{R}=\mathrm{H}$
$64 \mathrm{R}=\mathrm{M}$ -<smiles>CC=Cc1c2cc(OC)c(c1OC)/C(=C\C(=O)c1ccccc1)C=CC(C)(C)O2</smiles>

65 E-isomer
Cissampeloflavone $\mathbf{6 7}$ is a chalcone-flavone dimer isolated from the aerial parts of Cissampelos pareira (Menispermaceae) with a good activity on $T$. $b$. rhodesiense bloodstream forms $\left(\mathrm{IC}_{50}=1 \mu \mathrm{M}\right)$ and a SI of 173 when compared to KB cells. ${ }^{56}$ However, other biflavonoids such as amentoflavone $\mathbf{6 8}$ and podocarpusflavones A $\mathbf{6 9}$ and B 70 isolated from the leaves of Celaenodendron mexicanum (Euphorbiaceae) were inactive on T. b. brucei. ${ }^{57}$

Several diarylheptanoids isolated from species of the Zingiberaceae family have been tested for their antitrypanosomal activity. ${ }^{58,59}$ Curcumin 71, isolated from the rhizomes of Curcuma longa, displayed $\mathrm{IC}_{50}$ values of $0.83 \mu \mathrm{M}$ and $4.35 \mu \mathrm{M}$ for the bloodstream and procyclic forms of $T$. b. brucei, respectively. ${ }^{58}$ Four diarylheptanoids were obtained from the seeds of Aframomum letestuianum and showed different antitrypanosomal activity. Letestuianin $\mathrm{C} \mathbf{7 2}$ and $(4 Z, 6 E)-5$ hydroxy-1,7-bis(4-hydroxyphenyl)hepta-4,6-dien-3-one $\mathbf{7 3}$ were effective with $\mathrm{IC}_{50}$ values in the range of $4-9 \mu \mathrm{M}$ on the bloodstream forms of different $T$. brucei spp. isolates. In comparison, 
letestuianins A $\mathbf{7 4}$ and B $\mathbf{7 5}$ were inactive. It should be noted that the additional methoxy group in $\mathbf{7 4}$ compared to $\mathbf{7 3}$ renders it inactive. ${ }^{59}$

Two arylnaphthalide lignans were isolated from the aerial parts of Phyllanthus piscatorum (Euphorbiaceae): justicidin B 76 and its $\mathrm{C}_{11}$-hydroxylated derivative, piscatorin 77. Compound 76 exhibited a strong activity against the bloodstream trypomastigotes of $T . b$. rhodesiense $\left(\mathrm{IC}_{50}=0.55 \mu \mathrm{M}\right)$ while 77 was 11 times less active $\left(\mathrm{IC}_{50}=6.1 \mu \mathrm{M}\right)$. Compound 76 was also more cytotoxic than 77 , with $\mathrm{IC}_{50}$ values ranging from 0.6 to $13 \mu \mathrm{M}$ depending on the mammalian cell line tested. ${ }^{60}$<smiles>COc1ccc(-c2oc3cc4oc(-c5ccc(O)c(OC)c5)cc(=O)c4c(O)c3c2C(=O)c2c(O)cc(OC)cc2OC)cc1</smiles>

67<smiles>[R2]Oc1cc(O)c2c(=O)cc(-c3ccc(O)c(-c4c(O)cc(O)c5c(=O)cc(-c6ccc([R20])cc6)oc45)c3)oc2c1</smiles>

$68 \mathrm{R}^{1}, \mathrm{R}^{2}=\mathrm{H}$ $69 \mathrm{R}^{1}=\mathrm{H}, \mathrm{R}^{2}=\mathrm{Me}$ $70 \mathrm{R}^{1}, \mathrm{R}^{2}=\mathrm{Me}$<smiles>[R]c1cc(/C=C/C(=O)/C=C(O)/C=C/c2cc([R])c(O)c([R])c2)cc([R])c1O</smiles>

$71 \mathrm{R}^{1}, \mathrm{R}^{4}=\mathrm{OMe}, \mathrm{R}^{2}, \mathrm{R}^{3}=\mathrm{H}$ $72 R^{1}, R^{2}, R^{3}, R^{4}=H$ 1,2- and 6,7-dihydro $73 R^{1}, R^{2}, R^{3}, R^{4}=H 1,2$-dihydro $74 R^{1}, R^{2}, R^{4}=H, R^{3}=O M e 1,2$-dihydro $75 \mathrm{R}^{1}, \mathrm{R}^{4}=\mathrm{H}, \mathrm{R}^{2}, \mathrm{R}^{3}=\mathrm{OMe}$ 1,2-dihydro<smiles>[R]C1OC(=O)c2c(cc3cc(OC)c(OC)cc3c2-c2ccc3c(c2)OCO3)C1[R]</smiles>

\subsection{Quinones}

It has been reported that quinones, especially 1,4-naphthoquinones such as plumbagin 78, can induce oxidative stress in trypanosomes ( $T$. congolense $e^{61}$ and $T$. cruzi $^{62}$ ). This may be explained by their reduction to semi-quinone radicals by enzymes such as those present in the mitochondrial electron transport chain and the trypanothione reductase, a key enzyme of the trypanosomal antioxidant thiol metabolism. Compound
78, which can be found in Drosera species (Droseraceae), is active on the mammalian stage of $T$. b. brucei $\left(\mathrm{IC}_{50}=1.5\right.$ $6.5 \mu \mathrm{M})^{24,62}$ while its reduced derivative, trans-isoshinanolone 79 is inactive $\left(\mathrm{IC}_{50}>65 \mu \mathrm{M}\right){ }^{24}$<smiles>[R7]C1([R7])c2cccc(O)c2C(=O)C[C@H]1C</smiles>

\section{$78 R^{1}, R^{2}=O 2,3$ dehydro} $79 \mathrm{R}^{1}=\mathrm{OH}, \mathrm{R}^{2}=\mathrm{H}$

Diospyrin 80, a bis-naphthoquinone isolated from the bark of Diospyros montana (Ebenaceae), as well as semi-synthetic derivatives, have been investigated for their antitrypanosomal activity in vitro on $T$. b. brucei bloodstream forms. The $\mathrm{IC}_{50}$ of $\mathbf{8 0}$ was $50 \mu \mathrm{M}$ while diospyrin dimethyl ether $\mathbf{8 1}$ and its hydroquinone form $\mathbf{8 2}$ were respectively 24 and 71 times more active than the parent compound $\left(\mathrm{IC}_{50}=2.1\right.$ and $0.7 \mu \mathrm{M}$ respectively) ${ }^{63}$ According to the authors, the enhanced activity of $\mathbf{8 2}$ as compared to the parent compound $\mathbf{8 0}$ could be due to the presence of the 4 hydroxyl groups in $\mathbf{8 2}$ which generate semiquinone radicals more easily through one-electron shift leading thus to an increase of the oxidative stress in trypanosomes. On the contrary, in 80, the hydrogen bond between the carbonyl and phenolic groups of one naphthalene ring reduces the electron availability explaining the lower activity of $\mathbf{8 0} .^{63}$<smiles>[R]Oc1c(C2=CC(=O)c3c(O)cc(C)cc3C2=O)c(C)cc2c1C(=O)C(=O)C=CC2=O</smiles>

Activity-guided fractionation of stem bark and root bark extracts of Kigelia pinnata (Bignoniaceae) allowed the isolation of one furanonaphthoquinone, 2-(1-hydroxyethyl)-naphtho[2,3-b]furan-4,9-quinone 83, and three naphthoquinoids: isopinnatal 84, kigelinol 85, and isokigelinol 86. Compounds 83 and $\mathbf{8 4}$ possessed a pronounced activity against both $T$. b. brucei and $T . b$. rhodesiense bloodstream forms $\left(\mathrm{IC}_{50}=0.12 \mu \mathrm{M}\right.$ and $0.045 \mu \mathrm{M}$ respectively for $\mathbf{8 3}$ and $0.37 \mu \mathrm{M}$ and $0.73 \mu \mathrm{M}$ for $\mathbf{8 4}$ ) with a certain selectivity compared to $\mathrm{KB}$ cells $\left(\mathrm{IC}_{50}=3.9 \mu \mathrm{M}\right.$ and $14.8 \mu \mathrm{M}$ for $\mathbf{8 3}$ and $\mathbf{8 4}$ respectively). Compounds $\mathbf{8 5}$ and $\mathbf{8 6}$ had a less potent antitrypanosomal activity with $\mathrm{IC}_{50}$ values from 1.4 to $21.3 \mu \mathrm{M}$ depending on the trypanosome tested ${ }^{64}$<smiles>CC(O)c1cc2c(o1)C(=O)c1ccccc1C2=O</smiles>

83

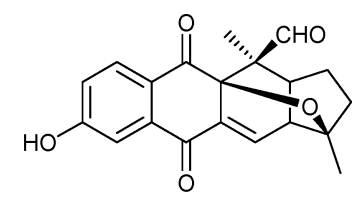

84
Bioactivity-guided fractionation of an extract from the aerial parts of Stephania dinklagei (Menispermaceae) led to the isolation of only one active compound on T. b. brucei bloodstream forms, aloe-emodin 87, an anthraquinone, along with inactive aporphinoid alkaloids. Compound $\mathbf{8 7}$ possessed a weak but rather selective antitrypanosomal activity $\left(\mathrm{IC}_{50}=14 \mu \mathrm{M}, \mathrm{SI}=\right.$ 75 compared to KB cells). ${ }^{65}$

Phenylanthraquinones are constitutionally unsymmetric biaryls that have already shown potential as antiplasmodial 


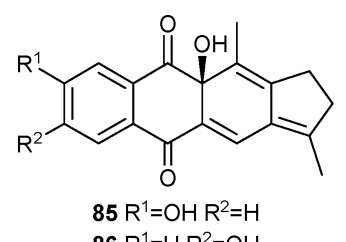<smiles>O=C1c2cccc(O)c2C(=O)c2c(O)cc(CO)cc21</smiles>

substances. ${ }^{66,67}$ Knipholone 88, first isolated from Kniphofia foliosa (Asphodelaceae), has a weak antitrypanosomal effect $\left(\mathrm{IC}_{50}\right.$ on $T$. b. rhodesiense $\left.=21.4 \mu \mathrm{M}\right)$. Other closely related compounds, differing only in the $O$-methylation pattern of the acetylphloroglucinol unit and/or in the oxidation state of the tricyclic portion (anthraquinone $v s$. anthrone) have been tested as well: knipholone anthrone $\mathbf{8 9}$ was more cytotoxic to L6 cells than to trypanosomes, $4^{\prime}$-O-demethylknipholone $\mathbf{9 0}$ was slightly more active on trypanosomes $\left(\mathrm{IC}_{50}=13.6 \mu \mathrm{M}\right){ }^{67}$ The $4^{\prime}$ $O-\beta$-D-glucoside of $\mathbf{9 0}, \mathbf{9 1}$, isolated from the roots of Bulbine frutescens (Asphodelaceae) was 13 times more active than $\mathbf{9 0}$ on T. b. brucei bloodstream trypomastigotes $\left(\mathrm{IC}_{50}=1.2 \mu \mathrm{M}\right)$ with some selectivity $\left(\mathrm{IC}_{100}\right.$ on L6 cells $\left.=154 \mu \mathrm{M}\right)$. Gaboroquinones A 92 and B 93, two isomers isolated from the same plant, were less active on trypanosomes: $\mathbf{9 2}$ was active in the same concentration range as $90\left(\mathrm{IC}_{50}=11.3 \mu \mathrm{M}\right)$, while 93 was inactive $\left(\mathrm{IC}_{50}=101 \mu \mathrm{M}\right)$. Neither of these two compounds exhibited any cytotoxic effect on mammalian cells at $200 \mu \mathrm{M}$. $^{66}$

Nok et al. showed that an ethanolic leaf extract of Mitracarpus scaber (Rubiaceae) cured mice infected with $T$. congolense at a dosage of $50 \mathrm{mg} \mathrm{kg}^{-1}$ given intraperitoneally for five days. Azaanthraquinone 94 (benz[g]isoquinoline-5,10dione), the active component isolated from this extract, inhibited the motility and induced lysis of $T$. congolense bloodstream forms in vitro. At $5 \mu \mathrm{M}, 94$ induced a complete lysis of the parasites in one hour. The addition of glycerol $(4 \mathrm{mM})$ to the medium rendered the compound more trypanocidal. The authors showed that 94 inhibits glycerol-3-phosphate-dependent mitochondrial oxygen consumption in T. congolense bloodstream forms. It blocks the TAO of the mitochondrial electron transport system by apparently the same mechanism as ascofuranone $49 .^{68}$

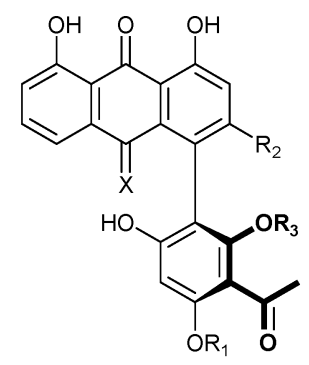

$88 \mathrm{X}=\mathrm{O}, \mathrm{R}_{1}, \mathrm{R}_{2}=\mathrm{Me}, \mathrm{R}_{3}=\mathrm{H}$

$89 X=\mathrm{H}_{2}, \mathrm{R}_{1}, \mathrm{R}_{2}=\mathrm{Me}, \mathrm{R}_{3}=\mathrm{H}$

$90 X=O, R_{1}, R_{3}=H, R_{2}=M e$

$91 \mathrm{X}=\mathrm{O}, \mathrm{R}_{1}=\beta$-D-glucopyranose, $\mathrm{R}_{2}=\mathrm{Me}, \mathrm{R}_{3}=\mathrm{H}$

$92 \mathrm{X}=\mathrm{O}, \mathrm{R}_{1}=\mathrm{H}, \mathrm{R}_{2}=\mathrm{CH}_{2} \mathrm{OH}, \mathrm{R}_{3}=\mathrm{Me}$

$93 \mathrm{X}=\mathrm{O}, \mathrm{R}_{1}=\mathrm{Me}, \mathrm{R}_{2}=\mathrm{CH}_{2} \mathrm{OH}, \mathrm{R}_{3}=\mathrm{H}$

\subsection{Terpenes}

Mikus et al. evaluated the effect of several mono- and sesquiterpenes, which are frequently present in essential oils, on the viability of $T$. b. brucei bloodstream forms and of human HL-60 cells. The only active monoterpene was terpinen-4-ol 95, a monoterpene alcohol, which exhibited a high antitrypanosomal activity $\left(\mathrm{IC}_{50}=0.13 \mu \mathrm{M}\right)$ with a remarkable SI of 1000 $\left(\mathrm{IC}_{50}\right.$ on HL-60 cells $\left.=133 \mu \mathrm{M}\right)$. The sesquiterpene alloaromadendrene 96 had a moderate activity $\left(\mathrm{IC}_{50}=9.3 \mu \mathrm{M}\right)$ but aromadendrene 97, a diastereoisomer, was 10 times less active on trypanosomes. ${ }^{69}(-)$-Boscialin 98 , a volatile aroma component of various plants, as well as three of its stereoisomers obtained synthetically $(\mathbf{9 9}, \mathbf{1 0 0}, \mathbf{1 0 1})$, were tested for their antitrypanosomal activity and cytotoxicity on human HT-29 cancer cells.
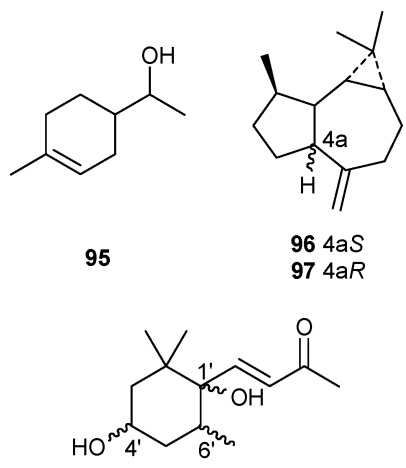

$$
\begin{aligned}
& 981 ' S 4^{\prime} S G^{\prime} R \\
& \mathbf{9 9} 1^{\prime} R 4^{\prime} R G^{\prime} S \\
& 1001^{\prime} R 4^{\prime} S \sigma^{\prime} R \\
& 1011^{\prime} S 4^{\prime} R 6^{\prime} S
\end{aligned}
$$

Only the natural $\mathrm{C}_{13}$-norisoprenoid 98 and its $1^{\prime}$-epimer $\mathbf{1 0 0}$ were active on $T$. $b$. brucei bloodstream trypomastigotes with small SI $\left(\mathrm{IC}_{50}=8.4\right.$ and $4 \mu \mathrm{M}, \mathrm{SI}=23$ and 9.4, respectively $){ }^{70}$

Ilimaquinone 102 and pelorol 103, two sesquiterpenes substituted with a quinone or hydroquinone moiety, were isolated from a tropical marine sponge Dactylospongia elegans and exhibited a weak effect on the mammalian stage of T. b. brucei $\left(\mathrm{IC}_{50}=21.5\right.$ and $46.7 \mu \mathrm{M}$ respectively $) .{ }^{71}$ Several sesquiterpene lactones isolated from Arnica and Inula species (Asteraceae) were tested for their antitrypanosomal activity on $T$. b. rhodesiense bloodstream trypomastigotes. The two most potent molecules were helenalin 104 and mexicanin I 105 which had $\mathrm{IC}_{50}$ values of 0.05 and $0.32 \mu \mathrm{M}$. When comparing this activity with the cytotoxicity on mammalian L6 cells, some selectivity was observed ( $\mathrm{SI}=19.5$ and 7.7 for $\mathbf{1 0 4}$ and 105). Stereochemistry seems to play an important role since $\mathbf{1 0 5}$, a diastereoisomer of $\mathbf{1 0 4}$, is less active on trypanosomes by a factor of six. Compounds 104 and 105 possess two $\alpha, \beta$ unsaturated carbonyl structures (cyclopentenone and $\alpha$-methylene- $\gamma$-lactone) which are potential alkylation centers that can react with sulfhydryl groups of various enzymes. The other sesquiterpene lactones tested, which possessed only one alkylation center, exhibited a less potent and less selective trypanocidal activity $\left(\mathrm{IC}_{50}=1.4-23.6 \mu \mathrm{M}\right)$. The authors postulate that the mechanism of action of these molecules towards trypanosomes might depend on interference with trypanothione metabolism (for example trypanothione reductase) leading to increased oxidative stress in the parasite. ${ }^{72}$

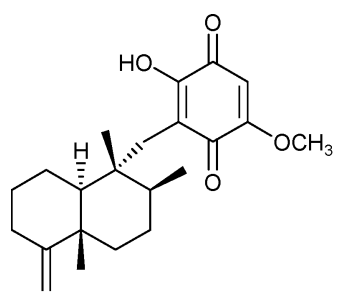

102

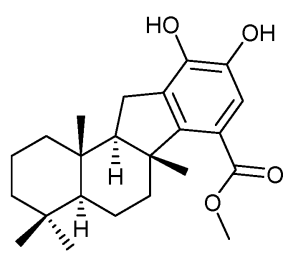

103

A diastereoisomer of the diterpene kolavenol 106, was isolated from a rootbark extract of Entada abysinica (Leguminosae), a plant traditionally used in Uganda to treat sleeping sickness. It showed a trypanocidal activity with an $\mathrm{IC}_{50}$ value of $8.6 \mu \mathrm{M}$ against $T$. $b$. rhodesiense bloodstream trypomastigotes. $^{73}$

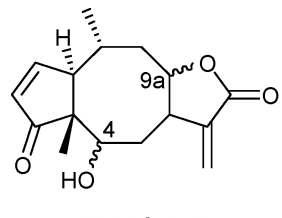

$1044 S, 9 a R$ $1054 \mathrm{R}, 9 \mathrm{aS}$

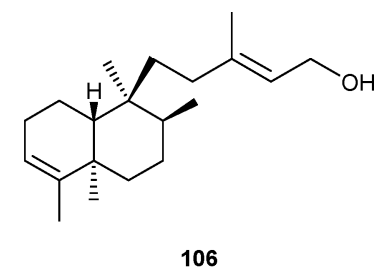


Several terpenoids, as well as a coumarin, were isolated from the leaves of Guarea rhophalocarpa (Meliaceae): only two lanostane triterpenoids showed some effect against the mammalian stage of T. b. brucei. 23-Hydroxy-5a-lanosta-7,9(11),24-triene-

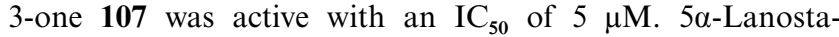
7,9(11),24-triene-3 $\alpha, 23$-diol 108, with a hydroxyl group on $\mathrm{C}_{3}$ instead of a ketone had an enhanced activity $\left(\mathrm{IC}_{50}=1.75 \mu \mathrm{M}\right)$ and was 12 times less cytotoxic to $\mathrm{KB}$ cells $\left(\mathrm{IC}_{50}=21.2 \mu \mathrm{M}\right){ }^{74}$ Various terpenoids were also isolated from the leaves of Celaenodendron mexicanum (Euphorbiaceae) but only one showed activity against $T$. b. brucei bloodstream forms: 3-oxotirucalla-7,24Z-dien-26-oic acid 109, a tirucalla-type triterpene, had $\mathrm{IC}_{50}$ values of $16.8 \mu \mathrm{M}$ and $137.6 \mu \mathrm{M}$ on trypanosomes and KB cells respectively. ${ }^{57}$ Two stigmastane-type steroids, vernoguinosterol 110 and vernoguinoside 111, isolated from the stem bark of Vernonia guineensis (Asteraceae), exhibited significant inhibitory activity against four strains of $T$. $b$. rhodesiense mammalian trypomastigotes with $\mathrm{IC}_{50}$ values in the range of 5-10 $\mu \mathrm{M} .^{75}$ Other sterols isolated from Guarea rhophalocarpa (Meliaceae) and Galphimia glauca (Malphigeaceae) were inactive on trypanosomes. ${ }^{52,74}$
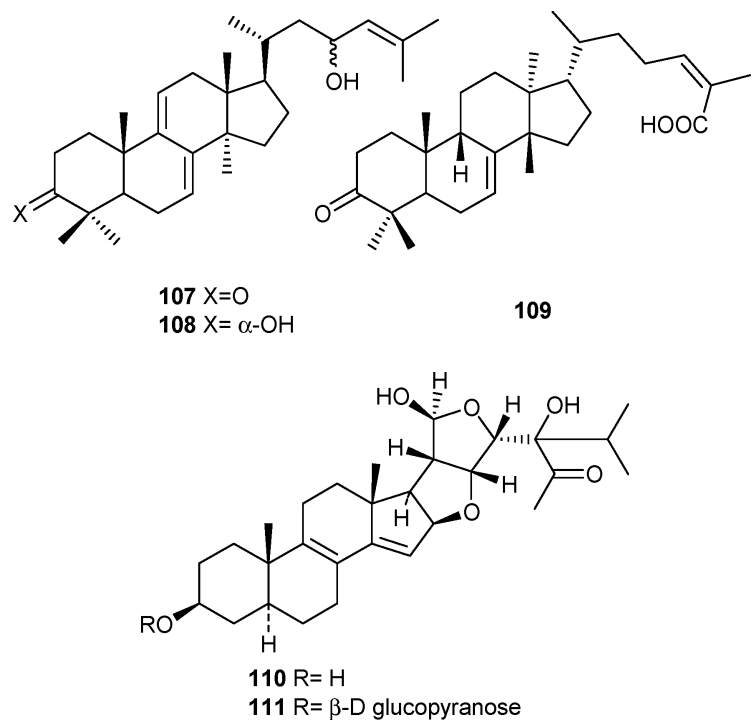

\subsection{Other metabolites}

Bio-guided-fractionation of a methylene chloride extract of the stems of Uvaria klaineana (Annonaceae) led to the isolation of klaivanolide 112 (5-acetoxy-7-benzoyloxymethyl-7H-oxepin-2one), a bisunsaturated seven-membered lactone which has a moderate activity on $T$. b. brucei bloodstream forms $\left(\mathrm{IC}_{100}=\right.$ $33.2 \mu \mathrm{M}){ }^{76}$

Aculeatins, a class of compounds with a 1,7-dioxadispiro[5.1.5.2]-pentadecan skeleton, have been isolated from the rhizome of Amomum aculeatum (Zingiberaceae) and exhibit a strong, but non selective, activity against the bloodstream trypomastigotes of $T$. b. rhodesiense. For example, aculeatin D 113 had an $\mathrm{IC}_{50}$ of $0.5 \mu \mathrm{M}$ and of $0.9 \mu \mathrm{M}$ on $T$. b. rhodesiense and $\mathrm{KB}$ cells respectively. ${ }^{77,78}$

Acetogenins, such as senegalene 114 and squamocine 115, isolated from the seeds of Annona senegalensis (Annonaceae)<smiles>CC(=O)OC1=CC(COC(=O)c2ccccc2)OC(=O)C=C1</smiles>

112

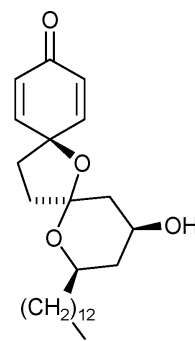

113 show activity against bloodstream forms of $T$. b. brucei $\left(\mathrm{IC}_{100}=\right.$ $16 \mu \mathrm{M})$. However, these metabolites also show a cytotoxicity against $\mathrm{KB}$ and monkey kidney cells (VERO cells) greater than that of vinblastine, an antitumor compound taken as reference. ${ }^{79}$

Different sulfur containing aliphatics, initially isolated from garlic bulb (Allium sativum Liliaceae), have been studied for their antitrypanosomal activity. $^{80-82}$ Diallyl trisulfide 116 is a chemically stable final transformation product of allicin that can be synthesized and is used in China to treat bacterial, fungal and parasitic infections in man. This product exhibits $\mathrm{IC}_{50}$ values in the range of $10-15 \mu \mathrm{M}$ when tested in vitro on bloodstream forms of $T$. b. brucei, T. b. gambiense, $T$. b. rhodesiense and of $30 \mu \mathrm{M}$ when tested on $T$. congolense bloodstream forms. Up to $140 \mu \mathrm{M}$, no noticeable morphological changes could be observed on fibroblasts. ${ }^{80} \mathrm{~A}$ fraction of the oily extract from garlic bulb, which apparently contained mainly diallyl disulfide 117, cured mice infected with $T$. b. brucei in four days when given intraperitoneally at a dose of $120 \mathrm{mg}$ $\mathrm{kg}^{-1}$ per day. Nok et al. showed that the extract interferes with the parasites' synthesis of membrane lipids. ${ }^{81}$ The effects of garlic extract and various of its purified components on metabolic enzymes, especially thiol-containing enzymes, have already been reported (e.g. Gallwitz et al.). ${ }^{82}$ They showed that ajoene 118, another garlic-derived natural product, affects the antioxidant thiol metabolism of $T$. cruzi, leading to increased oxidative stress by inhibition of the trypanothione reductase. $^{82}$

Manumycin A 119, an antibiotic produced by Streptomyces microorganisms, is an inhibitor of Ras farnesyltransferase, which is of interest for antitumor therapy. Compound 119 is potently active in vitro against the growth of both bloodstream and procyclic forms of $T$. b. brucei $\left(\mathrm{IC}_{50}=1.5\right.$ and $0.4 \mu \mathrm{M}$ respectively). Its mode of action seems complex: it does not affect trypanosomal protein or DNA synthesis nor cell cycle progression but inhibits farnesylation and causes significant mitochondrial damage possibly by interference with electron/ proton transport systems. In vivo $\mathbf{1 1 9}$ is well tolerated but fails to cure experimental trypanosomiasis in mice when administered intraperitoneally. ${ }^{83}$

Sinefungin 120, a natural nucleoside produced by Streptomyces grizeolus and S. incarnatus, is a structural analog of $S$-adenosylmethionine 121 (SAM), a molecule which plays an important role in the biosynthesis of polyamines and in transmethylations of proteins and lipids. It has been shown that $\mathbf{1 2 0}$ is a strong inhibitor of SAM-dependent transmethylation reactions. ${ }^{84}$ Compound 120 potently inhibits the in vitro growth of T. b. rhodesiense bloodstream trypomastigotes $\left(\mathrm{IC}_{50}=0.0004\right.$<smiles>CCCCCC(O)CC(O)C1CC[C@H](C2CC[C@@H]([C@H](O)CC3=C[C@@H](C)OC3=O)O2)O1</smiles><smiles>C=CCSSC=CC[SH](O)CC=C</smiles> 


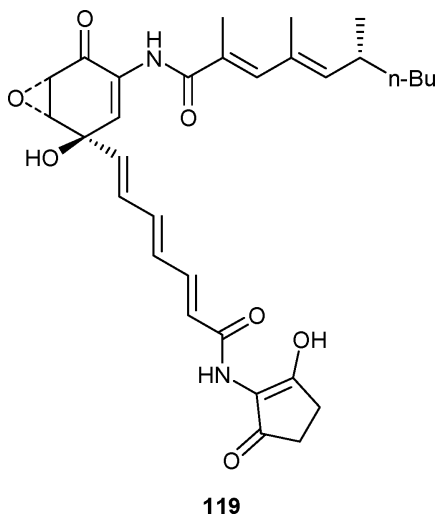

$\mu \mathrm{M})$ with a very high SI $\left(\mathrm{SI}>10^{6}\right) .{ }^{20}$ It is however much less active on the bloodstream forms of a diminazene- and melarsoprol-resistant T. b. brucei isolate $\left(\mathrm{IC}_{50}=7 \mu \mathrm{M}\right) .{ }^{85}$ In vivo 120 cures mice infected with $T$. b. brucei, T. congolense and T. vivax when administered intraperitoneally and is well tolerated in mice. ${ }^{86,87}$ However, unexpectedly, $\mathbf{1 2 0}$ proved to be very nephrotoxic at subcurative levels in goats blocking any further development. ${ }^{88}$<smiles>[R][X]C(CC[C@@H](N)C(=O)O)C[C@@H]1CC[C@H](n2cnc3c(N)ncnc32)O1</smiles>

$120 \mathrm{X}=\mathrm{CH} \mathrm{R}=\mathrm{NH}_{2}$

$121 \mathrm{X}=\mathrm{S}^{+} \mathrm{R}=\mathrm{CH}_{3}$

\section{Summary}

A great diversity of natural products has shown in vitro activity against African trypanosomes and for some of these products this activity seems to be quite selective. In this review, several compounds isolated from a natural source had an $\mathrm{IC}_{50}$ in the submicromolar range. Only 12 of them $(\mathbf{1 , 6 , 3 4 , 3 5 , 5 6 , 5 7 , 6 7 , 8 3}$ $\mathbf{8 4 , 9 5 , 1 0 4 , 1 2 0}$ ) were revealed to be relatively selective (SI $\geq 20)$ whereas no information on selectivity was given for two others (49 combined with glycerol and 71). Additionally, synthetic chemical modifications of natural substances, such as $\mathbf{3 7 , 4 2}$ $\mathbf{4 4 , 8 0}$, led to compounds which also exhibit activity, while the parent molecule does not, illustrating once again how natural products can serve as a basis to develop derivatives with increased activity and/or lower toxicity. Nevertheless, there are very few natural products that have been evaluated in rodent models of African trypanosomiasis. In this review, three pure active principles were able to cure infected mice $(49,117,120)$. The mode of action of the active natural compounds has almost never been thoroughly studied; only possible mechanisms have been suggested. The incomplete knowledge of these promising antitrypanosomal natural products calls for more in-depth interdisciplinary investigations to identify new leads.

In addition to searching in nature for much-needed leads for antitrypanosomal agents, it is vital that plants used in traditional medicine to treat African trypanosomiasis be validated and their active principles identified in order to design inexpensive standardized medicines for developing countries, which are sadly lacking up to now.

\section{Acknowledgements}

The support by the Belgian National Fund for Scientific Research is gratefully acknowledged (fellowship to S. H.).

\section{References}

1 Control and surveillance of African trypanosomiasis. Report of a WHO Expert Committee, World Health Organization Technical Report Series, World Health Organization, Geneva, 1998, pp. I-VI, pp. 1-114.

2 L. V. Kirchhoff, in Mandell, Douglas, and Benett's principles and practice of infectious diseases, ed. G. L. Mandell, J. E. Benett, and R. Dolin, Churchill Livingstone, Philadelphia, 2000, pp. 2853-2858.

3 R. Brun, H. Hecker and Z. R. Lun, Vet. Parasitol., 1998, 79, 95.

4 WHO report on global surveillance of epidemic-prone infectious diseases, World Health Organization, 2000; http://www.who.int/csr/ resources/publications/surveillance/en/a_tryps.pdf.

5 M. P. Barrett, Lancet, 1999, 353, 1113.

6 (a) A. James, in Trypanosomiasis and leishmaniasis: biology and control, ed. G. Hide, J. C. Mottram, G. H. Coombs, and P. H. Holmes, CAB international, Wallingford, 1997, pp. 327-334; (b) K. Vickerman and F. E. G. Cox, The protozoa, in Introductory Studies in Biology, ed. S. W. Hurry, John Murray, London, 1967, pp. 1-57.

7 M. P. Barrett, R. J. S. Burchmore, A. Stich, J. O. Lazzari, A. C. Frasch, J. J. Cazzulo and S. Krishna, Lancet, 2003, 362, 1469.

8 D. S. Fries and A. H. Fairlamb, in Burger's Medicinal Chemistry and Drug Discovery: Chemotherapeutic Agents, ed. D. J. Abraham, John Wiley \& Sons, Inc., 2003, pp. 1033-1087.

9 R. Brun, R. Schumacher, C. Schmid, C. Kunz and C. Burri, Trop. Med. Int. Health, 2001, 6, 906.

10 D. Legros, G. Ollivier, M. Gastellu-Etchegorry, C. Paquet, C. Burri, J. Jannin and P. Buscher, Lancet Infect. Dis., 2002, 2, 437.

11 B. Bouteille, O. Oukem, S. Bisser and M. Dumas, Fundam. Clin. Pharmacol., 2003, 17, 171.

12 D. J. Newman, G. M. Cragg and K. M. Snader, J. Nat. Prod., 2003, 66, 1022 .

13 S. Tagboto and S. Townson, Adv. Parasitol., 2001, 50, 199.

14 M. d. R. Camacho, S. L. Croft and J. D. Phillipson, Curr. Opin. Investig. Drugs, 2000, 2, 47.

15 A. Fournet and V. Muñoz, Curr. Top. Med. Chem., 2002, 2, 1215.

16 O. Kayser, A. F. Kiderlen and S. L. Croft, Parasitol. Res., 2003, 90, S55.

17 M. J. Chan-Bacab and L. M. Peña-Rodriguez, Nat. Prod. Rep., 2001, 18, 674 .

18 S. Sepulveda-Boza and B. K. Cassels, Planta Med., 1996, $62,98$.

19 C. W. Wright, in Trease and Evans Pharmacognosy, ed. W. C. Evans and W. B. Saunders, Edinburgh, 2002, pp. 407-413.

20 R. Kaminsky, C. Schmid and R. Brun, In Vitro Toxicol., 1996, 9, 315 .

21 K. Merschjohann, F. Sporer, D. Steverding and M. Wink, Planta Med., 2001, 67, 623

22 M. d. R. Camacho, J. D. Phillipson, S. L. Croft, P. Rock, S. J. Marshall and P. L. Schiff, Jr., Phytother. Res., 2002, 16, 432.

23 G. Dreyfuss, D. P. Allais, H. Guinaudeau and J. Bruneton, Ann. Pharm. Fr., 1987, 45, 243.

24 G. Bringmann, V. Hoerr, U. Holzgrabe and A. Stich, Pharmazie, $2003, \mathbf{5 8}, 343$

25 G. Bringmann, K. Messer, K. Wolf, J. Muhlbacher, M. Grüne, R. Brun and A. M. Louis, Phytochemistry, 2002, 60,389.

26 G. Bringmann, A. Hamm, C. Günther, M. Michel, R. Brun and V. Mudogo, J. Nat. Prod., 2000, 63, 1465 .

27 G. Bringmann, K. Messer, B. Schwobel, R. Brun and L. A. Assi, Phytochemistry, 2003, 62, 345.

28 G. Bringmann, M. Wohlfarth, H. Rischer, J. Schlauer and R. Brun, Phytochemistry, 2002, 61, 195.

29 G. Bringmann, K. Messer, R. Brun and V. Mudogo, J. Nat. Prod., 2002, 65, 1096 .

30 G. Bringmann, W. Saeb, M. Ruckert, J. Mies, M. Michel, V. Mudogo and R. Brun, Phytochemistry, 2003, 62, 631.

31 A. I. Waechter, A. Cave, R. Hocquemiller, C. Bories, V. Muñoz and A. Fournet, Phytother. Res., 1999, 13, 175.

32 S. Hoet, C. Stévigny, S. Block, F. Opperdoes, P. Colson, B. Baldeyrou, A. Lansiaux, C. Bailly and J. Quetin-Leclercq, Planta Med., in press.

33 J. J. Nair, A. K. Machocho, W. E. Campbell, R. Brun, F. Viladomat, C. Codina and J. Bastida, Phytochemistry, 2000, 54, 945.

34 M. R. Herrera, A. K. Machocho, J. J. Nair, W. E. Campbell, R. Brun, F. Viladomat, C. Codina and J. Bastida, Fitoterapia, 2001, 72,444 .

35 M. R. Herrera, A. K. Machocho, R. Brun, F. Viladomat, C. Codina and J. Bastida, Planta Med., 2001, 67, 191.

36 J. Labrana, A. K. Machocho, V. Kricsfalusy, R. Brun, C. Codina, F. Viladomat and J. Bastida, Phytochemistry, 2002, 60, 847.

37 A. D. Wright, E. Goclik, G. M. Konig and R. Kaminsky, J. Med. Chem., 2002, 45, 3067. 
38 G. Kirsch, G. M. Kong, A. D. Wright and R. Kaminsky, J. Nat Prod., 2000, 63, 825 .

39 B. R. Copp, O. Kayser, R. Brun and A. F. Kiderlen, Planta Med., 2003, 69, 527.

40 T. H. M. Jonckers, S. van Miert, K. Cimanga, C. Bailly, P. Colson, M. C. De Pauw-Gillet, H. van den Heuvel, M. Claeys, F. Lemiere, E. L. Esmans, J. Rozenski, L. Quirijnen, L. Maes, R. Dommisse, G. L. F. Lemiere, A. J. Vlietinck and L. Pieters, J. Med. Chem., 2002, 45, 3497.

41 J. Scovill, E. Blank, M. Konnick, E. Nenortas and T. Shapiro, Antimicrob. Agents Chemother, 2002, 46, 882.

42 A. L. Bodley and T. Shapiro, Proc. Natl. Acad. Sci. U. S. A, 1995, 92, 3726.

43 A. L. Bodley, M. C. Wani, M. E. Wall and T. Shapiro, Biochem. Pharmacol., 1995, 50, 937 .

44 C. Nihei, Y. Fukai and K. Kita, Biochim. Biophys. Acta, 2002, 1587, 234.

45 N. Minagawa, Y. Yabu, K. Kita, K. Nagai, N. Ohta, K. Meguro, S. Sakajo and A. Yoshimoto, Mol. Biochem. Parasitol., 1997, 84, 271.

46 Y. Yabu, N. Minagawa, K. Kita, K. Nagai, M. Honma, S. Sakajo, T. Koide, N. Ohta and A. Yoshimoto, Parasitol. Int., 1998, 47, 131.

47 Y. Yabu, A. Yoshida, T. Suzuki, C. Nihei, K. Kawai, N. Minagawa T. Hosokawa, K. Nagai, K. Kita and N. Ohta, Parasitol. Int., 2003, 52, 155.

48 T. Koide, M. Nose, M. Inoue, Y. Ogihara, Y. Yabu and N. Ohta, Planta Med., 1998, 64, 27.

49 M. Nose, T. Koide, K. Morikawa, M. Inoue, Y. Ogihara, Y. Yabu and N. Ohta, Biol. Pharm. Bull., 1998, 21, 583.

50 K. Asres, F. Bucar, E. Knauder, V. Yardley, H. Kendrick and S. L. Croft, Phytother. Res., 2001, 15, 613.

51 B. Räz, Isolation and evaluation of antiparasitic lead compounds from African medicinal plants, Ph.D. Thesis, Universität Basel, 1998 , pp. 216

52 M. d. R. Camacho, J. D. Phillipson, S. L. Croft, D. Marley, G. C. Kirby and D. C. Warhurst, J. Nat. Prod., 2002, 65, 1457.

53 A. C. Frasch, J. J. Cazzulo and A. O. Stoppani, Comp. Biochem. Physiol. B, 1978, 61, 207.

54 B. C. Elford, M. F. Roberts, J. D. Phillipson and R. J. Wilson, Trans R. Soc. Trop. Med. Hyg., 1987, 81, 434.

55 P. K. Tarus, A. K. Machocho, C. C. Lang'at-Thoruwa and S. C. Chhabra, Phytochemistry, 2002, 60, 375.

56 I. Ramirez, A. Carabot, P. Melendez, J. Carmona, M. Jimenez, A. V. Patel, T. A. Crabb, G. Blunden, P. D. Cary, S. L. Croft and M. Costa, Phytochemistry, 2003, 64, 645.

57 M. d. R. Camacho, R. Mata, P. Castaneda, G. C. Kirby, D. C Warhurst, S. L. Croft and J. D. Phillipson, Planta Med., 2000, 66 463.

58 M. Nose, T. Koide, Y. Ogihara, Y. Yabu and N. Ohta, Biol. Pharm. Bull., 1998, 21, 643.

59 P. Kamnaing, A. Tsopmo, E. A. Tanifum, M. H. K. Tchuendem, P. Tane, J. F. Ayafor, O. Sterner, D. Rattendi, M. M. Iwu, B. Schuster and C. Bacchi, J. Nat. Prod., 2003, 66, 364.

60 J. Gertsch, R. T. Tobler, R. Brun, O. Sticher and J. Heilmann, Planta Med., 2003, 69, 420.

61 N. K. Cenas, D. Arscott, C. H. Williams, Jr. and J. S. Blanchard, Biochemistry, 1994, 33, 2509.
62 L. Salmon-Chemin, E. Buisine, V. Yardley, S. Kohler, M.-A. Debreu, V. Landry, C. Sergheraert, S. L. Croft, R. L. Krauth-Siegel and E. Davioud-Charvet, J. Med. Chem., 2001, 44, 548

63 V. Yardley, D. Snowdon, S. L. Croft and B. Hazra, Phytother. Res., 1996, 10, 559.

64 S. V. K. Moideen, P. J. Houghton, P. Rock, S. L. Croft and F. Aboagye-Nyame, Planta Med., 1999, 65, 536.

65 M. d. R. Camacho, G. C. Kirby, D. C. Warhurst, S. L. Croft and J. D. Phillipson, Planta Med., 2000, 66, 478.

66 B. M. Abegaz, M. Bezabih, T. Msuta, R. Brun, D. Menche, J. Muehlbacher and G. Bringmann, J. Nat. Prod., 2002, 65, 1117

67 G. Bringmann, D. Menche, J. Kraus, J. Muhlbacher, K. Peters, E.-M. Peters, R. Brun, M. Bezabih and B. M. Abegaz, J. Org. Chem., 2002, 67, 5595 .

68 A. J. Nok, Cell Biochem. Funct., 2002, 20, 205.

69 J. Mikus, M. Harkenthal, D. Steverding and J. Reichling, Planta Med., 2000, 66, 366.

70 J. Busch, Y. Grether, D. Ochs and U. Sequin, J. Nat. Prod., 1998, 61, 591

71 E. Goclik, G. M. Konig, A. D. Wright and R. Kaminsky, J. Nat. Prod., 2000, 63, 1150.

72 T. J. Schmidt, R. Brun, G. Willuhn and S. A. Khalid, Planta Med., 2002, 68, 750

73 F. Freiburghaus, A. Steck, H. Pfander and R. Brun, J. Ethnopharmacol., 1998, 61, 179.

74 M. d. R. Camacho, J. D. Phillipson, S. L. Croft, G. C. Kirby, D. C. Warhurst and P. N. Solis, Phytochemistry, 2001, 56, 203.

75 A. T. Tchinda, A. Tsopmo, P. Tane, J. F. Ayafor, J. D. Connolly and O. Sterner, Phytochemistry, 2002, 59, 371.

76 B. Akendengue, F. Roblot, P. M. Loiseau, C. Bories, E. NgouMilama, A. Laurens and R. Hocquemiller, Phytochemistry, 2002, 59, 885 .

77 J. Heilmann, S. Mayr, R. Brun, T. Rali and O. Sticher, Helv. Chim. Acta, 2000, 83, 2939

78 J. Heilmann, R. Brun, S. Mayr, T. Rali and O. Sticher, Phytochemistry, 2001, 57, 1281.

79 S. Sahpaz, C. Bories, P. M. Loiseau, D. Cortes, R. Hocquemiller, A. Laurens and A. Cave, Planta Med., 1994, 60, 538.

80 Z. R. Lun, C. Burri and M. Menzinger and R. Kaminsky, Ann. Soc. Belg. Med. Trop., 1994, 74, 51.

81 A. J. Nok and S. Williams and P. C. Onyenekwe, Parasitol. Res., $1996, \mathbf{8 2}, 634$

82 H. Gallwitz, S. Bonse, A. Martinez-Cruz, I. Schlichting, K. Schumacher and R. L. Krauth-Siegel, J. Med. Chem., 1999, 42, 364.

83 B. R. S. Ali, A. Pal, S. L. Croft, R. J. K. Taylor and M. C. Field, Mol. Biochem. Parasitol., 1999, 104, 67.

84 C. J. Bacchi, B. Goldberg, J. Garofalo-Hannan, D. Rattendi, P. Lyte and N. Yarlett, Biochem. J., 1995, 309, 737.

85 R. Kaminsky and E. Zweygarth, Antimicrob. Agents Chemother, $1989,33,881$.

86 D. K. Dube, G. Mpimbaza, A. C. Allison, E. Lederer and L. Rovis, Am. J. Trop. Med. Hyg., 1983, 32, 31.

87 E. Zweygarth and D. Rottcher, Parasitol. Research, 1989, 75, 178.

88 E. Zweygarth, D. Schillinger, W. Kaufmann and D. Rottcher, Trop. Med. Parasitol., 1986, 37, 255. 